\section{An Autobiography}

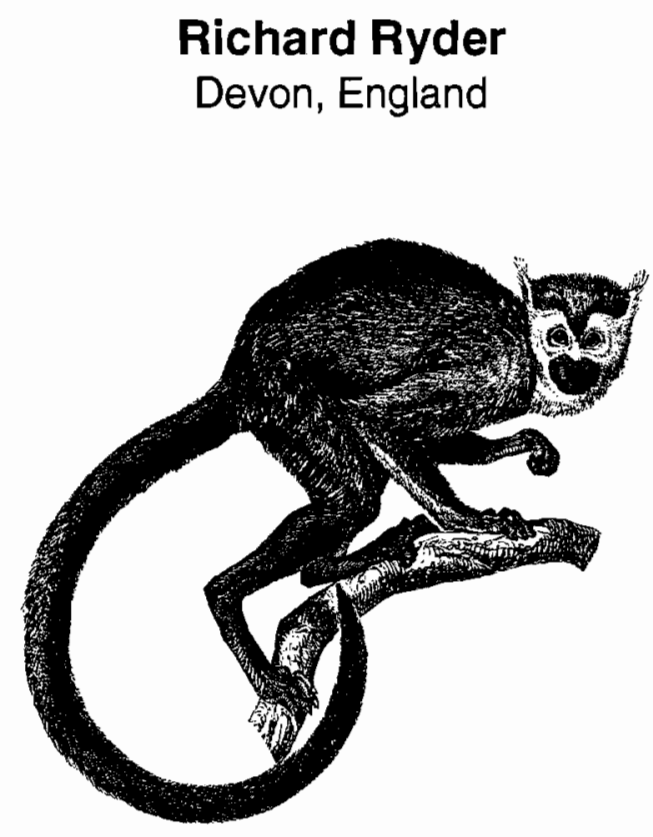

Long before I began campaigning against speciesism in $1969 \mathrm{I}$ had felt on the same wavelength as other sentients. I shared my bedroom with a monkey for about three years. His name was Bimbo and he had been "rescued" by my mother from a pet shop. She went on to rescue others, accommodating them in a spacious cage in the garden and taking some of them for walks in the woods. We used to have a photograph of a South American capuchin swinging at the top of a British larch tree!

I suppose my childhood was full of animals. Both my parents loved dogs and, during an unhappy adolescence, probably my closest friend was Toby, the family mongrel-stout-hearted and amiable, he could share a joke. We walked for hours together across the hills and through the woodland and I grew to love the wind, the rain, the trees and animals.

My human family was a large one. I am very much the youngest of ten children. It was when I began to grow up that my mother had to resort to monkeys to satisfy her strong maternal feelings! She also kept cats and talking birds. Yet ingrained in the family culture on my father's side was the old idea of human superiority and I was brought up to shoot and fish. When

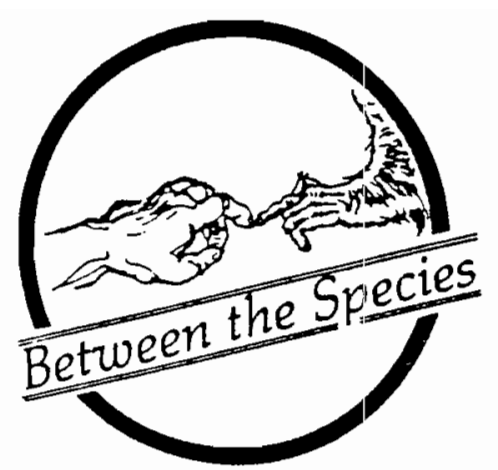

I recoiled at the obvious sufferings of my prey I was chided for being silly. Although it was considered the proper thing to do to kill an animal "cleanly" and to put wounded creatures "out of their misery" swiftly, the basic right of humankind to dominate and tyrannise was not to be challenged. Killing and exploiting animals was something that made a man a man. Yet I never really doubted that we sentients were all alike-and I owe that mainly to my mother.

My father, one of the last of the old sort of English squire, owned thousands of acres of wildlife-rich moorland, forestry and farmland, all of which had been in the family for generations. He wore the same huge hobnailed shoes and leather-patched tweed jackets decade after decade and ruled his estate with a feudal firmness and sense of duty. He was sometimes fierce but always fair.

As part of the "privileged" upper four percent, I was sent to boys' boarding schools between eight and eighteen where I was caned and bullied and forced to undergo almost continuous physical and mental hardship. The old adage, that anyone who survived a pre 1960's British "Public School" would find being stranded in Siberia quite comfortable, is no joke. The system was (unconsciously perhaps) designed to make or break you. If you survived it you emergerl as tough, unsentimental and well disciplined. Some of those who were broken by the system never recovered as human

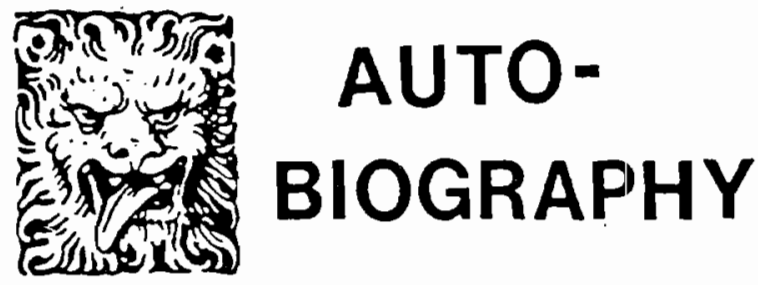


beings. Yet perhaps the most interesting products of this paramilitary training were those who outwardly survived while inwardly dissenting; I suppose I was one of these. Our inner lives were intense and highly complex, riven by ambivalence and conflict. Basically an exceptionally sensitive boy, I suffered horribly at school, yet I thought my way through it on my own. Much of my work has been built upon the scar-tissue of those years. We had little contact with nonhumans while at school. But I remember passionately fighting an unsuccessful environinental campaign in 1955 to stop the local vicar cutting down some magnificent thousand years old yew trees in the Abbey Close.

Despite all attempts to give me the traditional stiff upper lip I remained fragile, analytical and angry. To an extent I rebelled against my traditional background. I questioned everything: God, the social order, orthodox views of right and wrong. Very often experiencing pain myself, I grew to abhor it.

At Cambridge University I found the freedom intoxicating and wasted much time on "wine, women and song." But although appearing extrovert, there was also a very introvert part of me. I seemed jolly but was often depressed, anxious and preoccupied with morbid thoughts. I decided to study Experimental Psychology in order to sort myself out but discovered, much to my dismay, a cold and cruel science-yet another manifestation of Anglo-Saxon machismo. No sissy introspection here, no nonsense about Freud and all those other foreigners! Oh no. As psychology went entirely against the grain of English culture it had to prove itself sound by being fanatically behaviourist.

I was horrified by what I discovered that psychologists were doing to animals. But nobody then challenged it. Indeed, I assumed it was my fault that I found it so distressing. I saw baboons kept in tiny cages for months awaiting experimental brain surgery and read reports of puppies being blinded, rats being shocked and monkeys driven mad in American and British laboratories.

When I left Cambridge in 1963 I went to Colunbia in New York. Hoping for a more tender-minded approach I became a Research Fellow in the Department of Social Psychology. Surely there would be no animal experiments here. There were-and they seemed even worse. Visiting the Psychology Department at Stanford I saw a cat, blinded and with her tail cut off, being made to walk around inside a wire drum in order to deprive her of sleep for days and nights on end. "What is the purpose of this?" I asked the professor, "Oh the kids have some crazy ideas. But it gives them a chance to learn how to handle animals," he said.

For me, that was a turning point. I returned to Britain more than ever determined to get out of behaviourism.

As a clinical psychologist I had been working at the Warneford Hospital in Oxford for a year or so before the next great step came. A patient was late and so I picked up a leading national newspaper, the Daily Telegraph, and saw there a small report about animal experimentation. A surge of anger (always my main motive force) swept over me and I wrote:-

It is not often pointed out that, since Darwin, scientists themselves cannot justify the torture of other species any more than the deliberate mistreatment of human beings, for they do not accept any essential difference between man and beast. There is, indeed, no way of disproving that an intelligent monkey has a greater potential for terror, misery and boredom than, say, a mentally retarded child. It is about time that civilisation's admirable concern for human rights was logically extended to our neighbouring species.

This was published, as the headline letter, on 7 April 1969. On 3 May I published another Daily Telegraph letter entitled "The Rights of Non Human Animals:"

The question of animal rights may be one in which this country can lead the world so that in the future civilised men will look back on our present iniquities with as much amazement as we now look back on slavery, child labour and the other great issues of 19 th century reform."

I ended expressing the "hope that one day the rights of non human animals will become a real election issue."

In retrospect, it seems strange that these ideas came out of me so well formed. They were entirely selfgenerated. I had never discussed these matters with anyone before (as far as I knew I was the only person who thought in this way) nor had I read any animal rights literature (such as it was in those days). Anyway, these letters marked the start of my campaigning against animal experiments, and coincided with the beginning of the whole modern revival of the animal rights movement. 
Almost exactly a year later, in April 1970, I went home one weekend to visit my parents in Dorset. After dinner the telephone rang. It was a local author, Monica Hutchings, to ask whether my father had given permission to some otter hunters with hounds to hunt on his land the next day. (He hadn't; but an older brother of mine had.) Enraged, I informed the local press and confronted sixty or so otter-killers, gun under my arm, at Wytch Farm. I resolved I would campaign nationally against otter hunting until it was prohibited by law. This I did, organising a score of disruptive demonstrations at otter hunts (and several harecoursing events as well) over the next three or four years using false trails, "anti-mate" sprays, snuff, hunting horns to draw off the hounds, placards reading "Only Rotters Hunt Otters" and, of course, the national media. Demonstrating to protect animals in this way was quite a novelty for the media in those days and so we became quite famous and one small demo, for example, resulted in no less than the front page photograph in the national Sunday Times. Major television programmes followed. Those who came with me on these demos were usually colleagues from the hospital at Oxford. But, as the publicity grew, we attracted supporters from further afield including delightful characters such as David Wetton and John Bryant, and a diminutive man called Ronnie Lee who was to go on in later years to form the Animal Liberation Front.

My own highly respectable group, however, always kept within the law. The most unorthodox practice we adopted was to join the otter hunts under false names in order to receive their lists of meetings. As 'Colonel John de Vere Walker' I regularly corresponded with the masters of hunts, decrying the dastardly tactics of us tiresome young hunt saboteurs. Sometimes we met with violence from the hunters but eventually we won and, after a lot of hard work by many besides myself, otter hunting became outlawed in 1978.

Meanwhile, the responses to my letters about animal experimentation had included contact from the author Brigid Brophy. That wonderful woman did two things. She put me in touch with three young philosophers at Oxford and invited me onto what was, I think, the first ever televised discussion of animal rights anywhere in the world. It was a Scottish Television programme, "The Lion's Share," in late 1969. I remember we both had stage fright and Brigid saying to me- "Think of the animals; it's too important to be frightened." The producer had allowed her to devote the programme to whatever subject she wanted.

The young philosophers were John Harris and, from Canada, Ros and Stanley Godlovitch. I found it exciting meeting people who thought as I did. There was almost a sense of destiny about our meetingswe were a clique of true idealists. Shortly after I met them they obtained a contract from Victor Gollancz to publish the pioneering Animals, Men and Morals and immediately invited me to write the longest chapter, which was on animal experiments.

I had already invented the concept of "speciesism" (which had come to me one day while in the bath at the old Tudor manor house at Sunningwell) and, early in 1970 , I privately published a leaflet of this title which read as follows:

\section{Speciesism}

Since Darwin, scientists have agreed that there is no 'magical' essential difference between human and other animals, biologicallyspeaking. Why then do we make an almost total distinction morally? If all organisms are on one physical continuum, then we should also be on the same moral continuum.

The word 'species', like the word 'race', is not precisely definable. Lions and tigers can interbreed. Under special laboratory conditions it may soon prove possible to mate a gorilla with a professor of biology--will the hairy offspring be kept in a cage or a cradle?

It is customary to describe Neanderthal Man as a separate species from ourselves, one especially equipped for Ice-Age survivall. Yet most archaeologists now believe that this nonhuman creature practised ritual burial and possessed a larger brain than we do. Suppose that the elusive Abominable Snowman, when caught, turns out to be the last survivor of this Neanderthal species, would we give him a seat at the UN or would we implant electrordes in his super-human brain?

I use these hypothetical, but possible examples, to draw attention to the illogicality 
of our present moral position as regards experiments with animals.

\begin{abstract}
About 5,000,000 laboratory animals, more and more of them Primates like ourselves, are killed every year in the UK alone, and numbers are now escalating out of control. There are only 12 Home Office Inspectors.
\end{abstract}

Quite apart from the right to live, one clear moral criterion is suffering; the suffering of imprisonment, fear and boredom as well as physical pain.

If we assume that suffering is a function of the nervous system then it is illogical to argue that other animals do not suffer in a similar way to ourselves-it is precisely because some other animals have nervous systems so like our own that they are so extensively studied.

The only arguments in favour of painful experiments on animals are: 1) that the advancement of knowledge justifies all evilswell does it? 2) that possible benefits for our own species justify mistreatment of other species-this may be a fairly strong argument when it applies to experiments where the chances of suffering are minimal and the probability of aiding applied medicine is great, but even so it is still just "speciesism," and as such it is a selfish emotional argument rather than a reasoned one.

If we believe it is wrong to inflict suffering upon innocent human animals then it is only logical, phylogenically-speaking, to extend our concern about elementary rights to the non-human animals as well. Do not be afraid to express your views. Contact MP's, professors, editors about this increasingly important moral issue.

Getting no response to this (I had circulated it in Oxford) I reprinted it a month or two later with a photograph of a poor little chimp dying of experimental syphilis and co-signed (in order to increase credibility) by a member of the University, David Wood. We circulated this second edition around the Oxford
Colleges but again received no reply. A little later, the young Andrew Linzey joined this "Oxford Group" and we staged some pioneering street demonstrations against animal experiments in 1971 and 1972, I think. These were some of the first such protests in Britain since the First World War.

It was shortly before Animals, Men and Morals was published in 1971 that I first met Peter Singer. He invited me to lunch in his college and subsequently came back to my house on several occasions where we discussed my ideas about speciesism. Peter's review of Animals, Men and Morals launched his own career in this field. Sometime later he asked me if I would co-author a book he was planning called Animal Liberation. I gave him a lot of material to use which I had collected for my forthcoming Victims of Science but declined his offer of co-authorship on the grounds that I was too busy campaigning! Needless to say, I have always regretted this. But my campaigning steadily expanded and, although I majored on laboratory animals, I also campaigned against fur, battery cages, veal crates, zoos, whale killing and so on.

In the event, my book lay at the publishers for nearly three years and so was published only a short while before Peter's first appeared in the US. But when it came out it really hit the big time and the issues of aninal rights, speciesism and animal experimentation, increasingly discussed during the early 1970's, received even more publicity. I had been interviewed on twelve British nationwide television and radio shows (and many local ones) by the end of the year and the newspapers, serious as well as popular, had taken up the cause; over and over again I plugged the idea of speciesism and the moral argument. We owe a lot to the backing of the media; from 1975 onwards in Britain they have been rooting strongly for the nonhumans. Before then it had been hard work; they had seen animal issues as a joke. Highly publicised tours followed for me in Canada and Australia (but never in the US where my book was rejected by publishers at that time as too subversive!)

I'm not claiming this publicity was all my achievement. The animal welfare issue in the UK, which had been quiet in the fifty years following the First World War, had begun to take off in the 1970's and campaigners such as Muriel Dowding and Clive Hollands were key figures. And there were many others, including the militant hunt saboteurs who helped to change the whole image of the movement. 
Those of us campaigning in the very early 1970's had revived a moribund interest in animal rights; furthermore, we instigated some of the tactics used for the next two decades worldwide: we deliberately set about making animal cruelty a media interest; we also made the issue respectable in academic circles; we highlighted the modern forms of abuse (pioneering, for example, the concerns over cosmetics testing, LD50's and Draize Tests) and we also, eventually, put animals into politics.

In 1972 I was elected to the Council of the Royal Society for the Prevention of Cruelty to Animals (RSPCA) - the world's oldest and largest animal welfare body and, unfortunately, at that time, stagnant and incompetent. So began the most bitter and backbreaking campaign of my life so far-the reform of a large organisation whose office-holders and staff did not want reform. I know only too well what Gorbachev and Yeltsin have had to face! Opposed every inch of the way by shortsighted and vindictive diehards, my friends and I struggled, eventually successfully, but often at considerable cost to our own health and wellbeing, to transform a society that was part of the British establishment-as well known as Buckingham Palace. We defined its policies, realigned its sights onto the twentieth century cruelties of factory-farming, animal experimentation and wildlife exploitation, and established the appropriate scientific machinery to deal with these. I persuaded it to use publicity, improved methods of investigation, and lobbying tactics and to set up Eurogroup--a highly important multinational organisation which has since successfully lobbied the European Parliament and Commission for over a decade. The RSPCA is now a thriving concern with a dynamic political record and an annual income of $£ 30$ million sterling.

In retrospect, I wonder whether it has been worth it. I have given thousands of hours to the RSPCA, free of charge, battling to achieve what to me has always been the obvious. Could I have done more for animals working elsewhere? There is, of course, rarely any gratitude shown to reformers and 'whistle-blowers' such as myself! We were sometimes referred to as the "Ryderites" and several newspapers scurrilously implied that our motives were an extreme left-wing conspiracy!

Over the years I have done some work for the International Fund for Animal Welfare and the contrast has been striking. IFAW's founder Brian Davies goes direct to the heart of an issue. He is a true innovator and has, for this reason, often come in for unfair criticism. It has, I feel, been my fortune to work with him on some of his remarkable campaigns to protect whales, seals and other wildlife. For IFAW I lobbied the European Parliament and the Commission (with author Richard Adams) in 1980 and 1981.

Another outstanding figure with whon I closely collaborated during the late 1970's and early 1980's is Lord Houghton - a former Chairman of the British Labour Party. With him and Clive Hollands I helped set up an era of cooperation between leading British animal welfare bodies. We then determined to "put animals into politics" and, in 1979, we succeeded in persuading all the major political parties in Britain to include animal protection policies in their Election Manifestos for the first time ever. We also succeeded in meeting a number of major Government Ministers.

The Thatcher era was not one sympathetic to animal welfare reform. Yet I saw my long campaign for laboratory animals culminate in the passage of the Animals (Scientific Procedures) Act in 1986. Unsatisfactory though it is, it has worked somewhat better than I feared. Also, we succeeded in improving the government machinery dealing with animals and two committees were set up to advise the Government on laboratory and farm animals. Needless to say, I was invited to be a member of neither.

During the 1980's I joined the Liberal Democratsthe centre party in Britain, and twice ran for election to Parliament. This is not easy to achieve under the archaic British electoral system. But I learned a lot more about politics. In dull moments I managed to find time to write another book Animal Revolution: Changing Attitudes Towards Speciesism which takes my ethical views a stage further. In the early 1970's I had put considerable emphasis upon speciesism, basing my ethics upon the (then) amazingly overlooked fact that Darwinism reveals us to be just one species among many others with whom we have kinship. Peter Singer had brilliantly popularised speciesism as a concept in America, but, increasingly, I found myself unable to accept his utilitarian principle that the pains of some individuals can be justified by the pleasures of others. So, during the early 1980's, I emphasised the idea of sentientism (Andrew Linzey's word) or painism - that morality should be based upon the (nontransferable) capacity of the individual to experience pain. In other words, I based rights upon painience. 
Today, I continue to be active in a transformed RSPCA while working professionally with Brian Davies in the newly formed Political Animal Lobby, meeting and talking with British political leaders, in the long hard business of persuading them to take the subject of animal protection as seriously as do millions of their electors. We made a little history when we met John Major at 10 Downing Street just before the 1992 General Election: the first time a British Prime Minister has agreed to a meeting with animal welfarists. We have also broken new and controversial ground by making large financial donations to all the major parties; the political process needing another kick start after stalling under Margaret Thatcher. (The Conservative Party have been doing much better on animal welfare recently.)

I live now, rather strangely, on two levels; that of the political pragmatist arguing over legislative details and that of the idealist searching for a well-honed moral theory.

There have been many failures over the years - on bloodsports, dog registration, the primate trade, battery cages and so on-but I can look back with some sense of achievement, on protected otters, the ban on tobacco experiments on dogs, the establishment of educational Dog Wardens, improvements in Government machinery, the reform of the RSPCA, the inauguration of a Europewide movement, assisting with the protection of seals, the stimulation of academic animal welfare research, the putting of animals on to the political agenda and the arousal of a major international debate. But none of this could have been done without the help of countless others. And now we must continue what has only just begun.

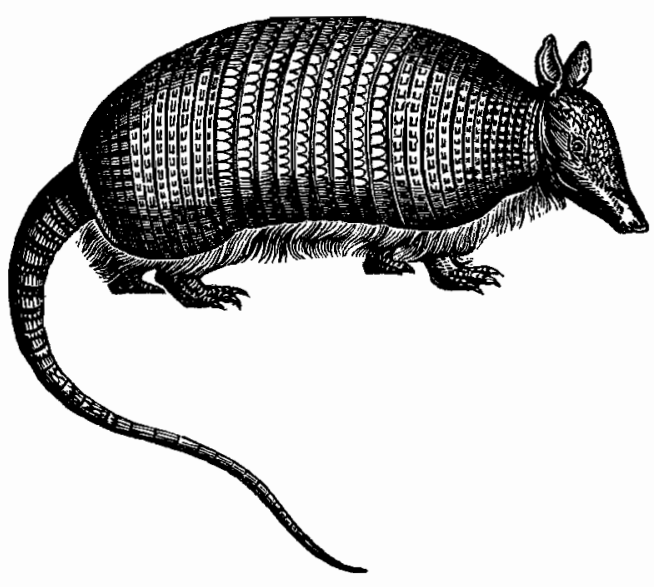

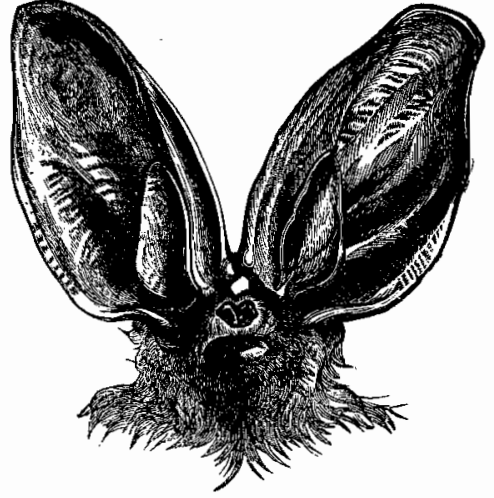

To the Editors:

The inaugural issue of Society and Animals: Social Scientific Studies of the Human Experience of Other Animals is now available.

It features articles on the symbolic role of animals in Native American rituals, the effect of labeling on the differential treatment of animals, the effectiveness of "pet facilitated therapy," student attitudes towards dissection, and researcher attitudes towards pain in their animal subjects.

$S \& A$ publishes manuscripts on applied uses of nonhuman animals (research, education, medicine, and agriculture); animals in the popular culture (entertainment, companion animals, animal symbolism); wildlife and the environment; sociopolitical movements, public policy, and the law.

Data-based discussion on ethical and policy issues involving our treatment of animals is encouraged.

Individual subscriptions are $\$ 30$ for volume 1 ( 2 issues), payable to PSYeta, P.O. Box 1297, Washington Grove, MD 20880. For information on manuscript submission, write to me at the same address.

Kenneth Shapiro, Ph. D. 